
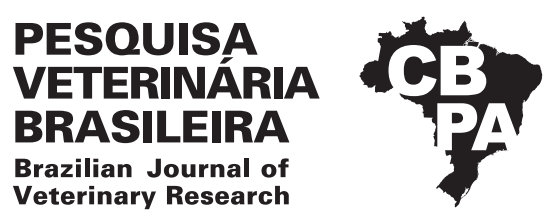

Pesq. Vet. Bras. 38(8):1537-1542, agosto 2018 DOI: 10.1590/1678-5150-PVB-5415

Original Article

ISSN 0100-736X (Print)

ISSN 1678-5150 (Online)

\title{
Occurrence of brucellosis, leptospirosis and neosporosis in cows with retained placenta in Southwest Paraná, Brazil ${ }^{1}$
}

\author{
Yuri F. Porto ${ }^{2}$, Adalgiza Pinto Neto ${ }^{2 *}$, Fabrício Bernardi², Marina Gabriela Possa ${ }^{2}$, \\ Marcelo F. Mota ${ }^{2}$, Antonio C. Martinez ${ }^{3}$, Luiz Sérgio Merlini ${ }^{4}$ and Rodolfo C. Berber ${ }^{5}$
}

\begin{abstract}
Porto Y.F., Pinto Neto A., Bernardi F., Possa M.G., Mota M.F., Martinez A.C., Merlini L.S. \& Berber R.C. 2018. Occurrence of brucellosis, leptospirosis and neosporosis in cows with retained placenta in Southwest Paraná, Brazil. Pesquisa Veterinária Brasileira 38(8):1537-1542. Curso de Medicina Veterinária, Universidade Federal da Fronteira Sul, Campus Realeza, Av. Edmundo Gaievisky 1000, Realeza, PR 85770-000, Brazil. E-mail: adalgiza.uffs@gmail.com

The aim of this study was to measure the occurrence of brucellosis, leptospirosis and neosporosis in cows from 25 family farms milk, with semi-intensive grazing system, located in the Southwest region of Paraná, Brazil. Eighty-four cows with retained placenta, between July 2013 to July 2014, diagnosed by the presence of fetal membranes in the uterus up to 12 hours after partum, decrease of appetite and of milk production, as well increase of rectal temperature were included into the study. The animals were submitted to blood collection for evaluating the seropositivity for brucellosis, leptospirosis and neosporosis. The blood was collected at 15 to 45 days postpartum, avoiding false negative results due to immune deficiency observed in the transition period. After collection, the blood was centrifuged, the serum was packed in three aliquots, identified and subsequently frozen. Serology was performed to diagnose brucellosis (technique of buffered acidified antigen), leptospirosis (through the microscopic agglutination test - MAT) and neosporosis (indirect immunofluorescence test). Animals were considered positive when presenting titer $>1: 100$ (leptospirosis) and 1:200 (neosporosis). No animal with placenta retention presented Brucella abortus bacteria; $39 \%$ (33/84) were reactive to one or more Leptospira serovars, $15 \%(13 / 84)$ were positive to Neospora caninum, and $4 \%(4 / 84)$ had both diagnosis, being reactive for leptospirosis and neosporosis. In conclusion, data from this experiment inspires greater attention to leptospirosis and neosporosis in dairy cattle presenting placenta retention in southwest Paraná.
\end{abstract}

INDEX TERMS: Brucellosis, leptospirosis, neosporosis, cattle, placenta, Paraná, Brazil, dairy cattle, reproductive diseases, reproductive efficiency, bacterioses, parasitoses.

RESUMO.- [Ocorrência de brucelose, leptospirose e neosporose em vacas com retenção de placenta no Sudoeste do Paraná, Brasil]. Objetivou-se com esse estudo

\footnotetext{
${ }^{1}$ Received on July 7, 2017.

Accepted for publication on August 29, 2017.

${ }^{2}$ Curso de Medicina Veterinária, Universidade Federal da Fronteira Sul (UFFS), Campus Realeza, Av. Edmundo Gaievisky 1000, Realeza, PR 85770-000, Brazil. *Corresponding author: adalgiza.uffs@gmail.com

${ }^{3}$ Departamento de Medicina Veterinária, Universidade Estadual de Maringá (UEM), Av. Colombo 5790, Zona 7, Maringá, PR 87020-900, Brazil.

${ }^{4}$ Programa de Pós-Graduação em Ciência Animal, Universidade Paranaense (Unipar), Praça Mascarenhas de Moraes 4282, Umuarama, PR 87502-210, Brazil.

${ }^{5}$ Curso de Medicina Veterinária, Universidade Federal de Mato Grosso (UFMT), Av. Alexandro Ferronato 1200, Setor Industrial, Sinop, MT 78550-730, Brazil.
}

avaliar a ocorrência de brucelose, leptospirose e neosporose em fêmeas bovinas de 25 propriedades leiteiras de agricultura familiar, mantidas em sistema de pastejo semi-intensivo, localizadas na Região Sudoeste do Paraná, Brasil. Para tanto, incluiu-se nesse estudo, 84 vacas diagnosticadas com retenção de placenta (RP) pela presença parcial ou total dos anexos fetais no útero após 12 horas do parto, diminuição do apetite e da produção de leite, como também aumento da temperatura retal. Os animais foram submetidos à coleta de sangue 15 a 45 dias pós-parto, a fim de evitar resultado falso negativo devido à imunodeficiência observada no período de transição. Após coleta, o sangue foi centrifugado, o soro aliquotado em três amostras, identificado e congelado. Para o diagnóstico sorológico de Brucelose utilizou-se o exame 
sorológico do antígeno acidificado tamponado, de leptospirose a técnica de soroaglutinação microscópica, e neosporose pela técnica de imunofluorescência indireta. Os animais foram diagnosticados positivos quando apresentaram título igual ou superior à 1:100 (leptospirose) e 1:200 (neosporose). Em nenhum dos 84 animais com RP foi detectada a presença da bactéria Brucella abortus. Desses, 39,28\% (33/84) foram reativos para um ou mais sorovares de Leptospira, 15,47\% $(13 / 84)$ foram positivos para Neospora caninum e 4,76\% (4/84) foram reativos para sorovares de Leptospira sp. e N. caninum, concomitantemente. Em conclusão, os dados deste estudo inspiram maior atenção à leptospirose e neosporose em bovinos leiteiros que apresentam retenção de placenta no sudoeste do Paraná.

TERMOS DE INDEXAÇÃO: Brucelose, leptospirose, neosporose, placenta, Paraná, gado de leite, doenças reprodutivas, eficiência reprodutiva, bovinos, bacterioses, parasitoses.

\section{INTRODUCTION}

Placenta retention decreases the reproductive efficiency (RE) of dairy herds, due to mechanical, nutritional, infectious and management issues. Among the infectious factors, reproductive diseases such as brucellosis, leptospirosis and neosporosis are well documented in Brazilian literature (Juffo \& Driemeier 2010, Nascimento \& Santos 2011, Nobre et al. 2012, Rezende et al. 2013), and that their identification is essential for both the reproductive success and the health of the herd. These diseases are considered zoonoses of importance to public health (Greca Junior 2010, Nascimento \& Santos 2011, Nobre et al. 2012).

Brucellosis is an infectious disease caused by Brucella abortus affecting farm animals, resulting in abortion in the final third of pregnancy, as well as premature births, sterility and low milk production. It causes losses and decreased reproductive efficiency (Zago 2011). The prevalence in Brazil ranges from $0.06 \%$ to $10.2 \%$ and becomes significant when considering the cattle herd of 220 million animals (Clementino \& Azevedo 2016).

Similarly, Leptospirosis is a bacterial disease caused by Leptospira sp. affecting various animal species and humans. Particularly in cattle, it promotes reproductive disorders such as placenta retention, infertility, decreased milk production and abortion, as well as contributing to the reduction of productivity and profitability in the global livestock (Magajevski et al. 2007, Rifatbegović \& Maksimovic 2011).

Neosporosis is a disease caused by the Neospora caninum protozoan, an obligate intracellular parasite, which affects several intermediate hosts in its cycle, such as sheep, horses, goats and cattle, and has dogs as the definitive host (Parra et al. 2008, Tembue et al. 2011, Carvalho et al. 2014). It also causes abortion in female bovines. In California, neosporosis is responsible for $42 \%$ of abortions and the damage is estimated at US\$ 25 million only in the production of milk. In Texas, the losses amount to approximately US\$ 24 million annually (Negrão 2006).

These diseases cause economic impact and decrease in reproductive rates (Laven \& Peters 1996, Santos 2010). The aim of this study was to measure the occurrence of brucellosis, leptospirosis and neosporosis in cows affected by placenta retention in southwest region from Paraná, Brazil.

\section{MATERIALS AND METHODS}

The study was carried out in 25 family farm milk farms, with small and medium-sized herds, in a semi-intensive grazing system, located in the municipalities of Nova Prata do Iguaçu, Nova Esperança do Sudoeste, Realeza and Salto do Lontra, all localized in southwest region of Paraná, Brazil (Fig.1). The southwest Paraná region is characterized by humid subtropical climate and annual average temperature of $19^{\circ} \mathrm{C}$ (IAPAR 2015).

From July 2013 to July 2014, eighty-four dairy cattle with retained placenta were diagnosed, being 7,14\% (6/84) from Nova Esperança do Sudoeste, 25\% (21/84) from Realeza, 27,38\% (23/84) from Nova Prata do Iguaçu and 40,48\% (34/84) from Salto do Lontra. Retained placenta were considered in the presence of fetal membranes in the uterus up to 12 hours after partum, associated to decrease of appetite and milk production, as well increase of rectal temperature.

The animals were submitted to blood collection for evaluating the seropositivity for brucellosis, leptospirosis and neosporosis. Blood was collected at the medial coccygeal artery, with prior asepsis, using disposable needles and vacuum siliconized tubes without anticoagulant for each animal (Dirksen et al. 1993). The blood was collected at 15 to 45 days postpartum, avoiding false negative results due to immune deficiency observed in the transition period. After collection, the blood was centrifuged (200rpm), and the serum was packed in three aliquots, identified and subsequently frozen.

Serology for brucellosis was performed by the antigen screening technique on buffered plate - AAT, in a certified veterinarian laboratory. The examination of leptospirosis was conducted at the Department of Preventive Veterinary Medicine and Animal Reproduction of the Paulista State University, Jaboticabal, through the microscopic agglutination test (MAT). Animals were considered positive if presenting titer $>1: 100$ (Hashimoto et al. 2012). Serology for neosporosis was performed at IMUNODOT (Imunodot Indústria Pesquisa Produtos para Diagnósticos Ltda.), Jaboticabal, by the indirect immunofluorescence technique (IIF). Animals presenting titer $>1: 200$ were considered as positive (Teixeira et al. 2010).

Data were subjected to descriptive analysis by PROC FREQ SAS (Statistical Analysis Sistem, Versão 9.2).

\section{RESULTS}

No animals with placenta retention presented brucellosis; $39.3 \%$ (33/84) were positive for leptospirosis; $15.5 \%$ (13/84) were positive for neosporosis; and 4.8\% (4/84) were positive for both leptospirosis and neosporosis, simultaneously. All animals were negative for brucellosis.

From the animals evaluated, 39\% (33/84) were positive for leptospirosis. The serovars detected were: Icterohaemorrhagiae at $33 \%(11 / 33)$, Hebdomadis at $27 \%$ (9/33), Wolffi at $24 \%$ (8/33), Gryppothyphosa at 18\% (6/33), Pyrogenes at $15 \%$ (5/33), Canicolaem at $12 \%(4 / 33)$, Pomona at $12 \%(4 / 33)$, Autumnalis at $9 \%(3 / 33)$, Australis at 6\% (2/33), Hardjo at $6 \%(2 / 33)$, Shermani at $6 \%(2 / 33)$, Coppenhagi at $3 \%(1 / 33)$, Tarassovi at $3 \%$ (1/33), and Patoc at $3 \%$ (1/33). In this study, concurrent infection with more than one type of serovar was found in 39\% (13/33) of the animals studied.

Vaccination for leptospirosis was performed in $26 \%$ of the analyzed cattle.

Only $4 \%$ of animals in this study presented an association between leptospirosis and neosporosis. 


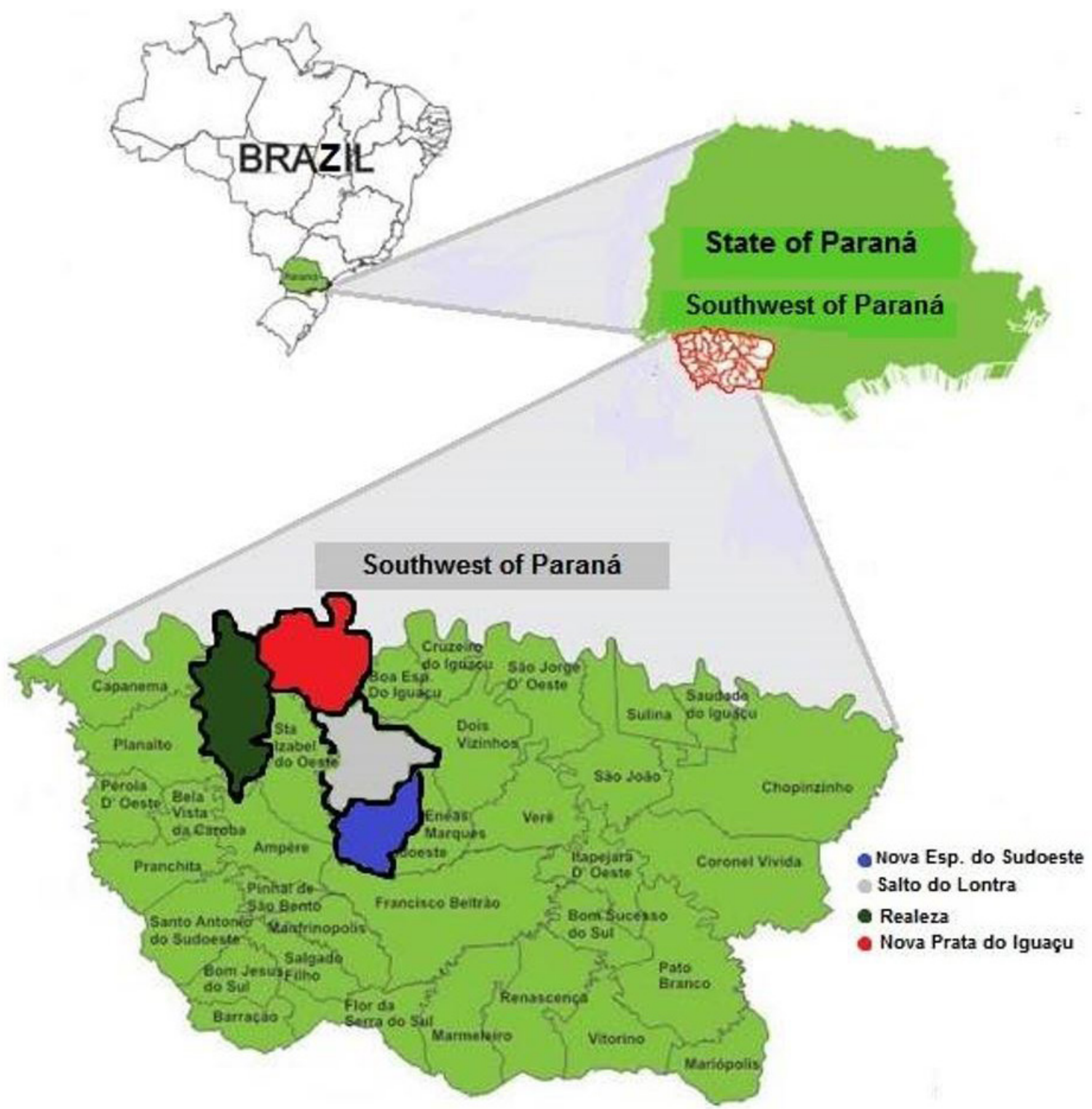

Fig.1. Map of the Southwest region of Paraná, highlighting the municipalities studied. Source: IBGE (2017).

\section{DISCUSSION}

The results found that brucellosis were according to the study conducted with dairy cattle in Parana by Santos et al. (2005). This suggests that the mandatory measures required by the National Program for Control and Eradication of Brucellosis and Tuberculosis (PNCEBT) implemented in 2006, is effective. Still, it must be noted that the animals come from properties that are in compliance with Instruction 62/2011, which established strict control of brucellosis, requiring regular prophylactic measures in dairy cattle (Brasil 2011). In Nigeria,
Alhaji et al. (2016) found prevalence of brucelosis in $10 \%$ of animals studied. In that country there are no official control programs for this disease, demonstrating that some public policies may be able to reduce the incidence of diseases that can be controlled, as reported by Bannantine et al. (2013).

Although no animal showed brucellosis, this disease affects approximately $5 \%$ of cattle (Brasil 2006) and is also related to retained placenta. Palmquist (2001) reported 7.9\% prevalence of brucellosis in dairy cattle from the north and east of Paraná. In other Brazilian studies, prevalence was found as $4 \%$ (Dias et al. 2009), 0.14\% (Sabedot et al. 2009), 0.32\% 
(Sartori \& Luguesi 2011), 0\% (Nascimento et al. 2008) and $3.5 \%$ (Viana et al. 2009)., while rich countries have already controlled the occurrence of this disease (Nielsen \& Yu 2010).

Although it seems small, when considering the national cattle herd, the prevalence of brucellosis can cause extensive damage, since this disease is related to a decrease in production and reproduction of animals (Sartori \& Luguesi 2011).

Mufinda et al. (2017) reported that brucellosis control measures include observing biosafety measures in the workplace, especially for professionals exposed to the risk of infection. Even if brucellosis does not occur in the animals studied, it is common to perform veterinary procedures in cows with placenta retention, which if carried out in animals infected with brucellosis and/or other infectious agents could result in contamination and/or dissemination of these agents.

The prevalence of icterohaemorrhagiae and hebdomadis serovars for leptospirosis in this study differs from the one reported in Hashimoto et al. $(2010,2012)$.

Hardjois the most prevalent serovar and it correlates with reproductive disorders in the region (Mineiro et al. 2007, Hashimoto et al. 2012, Menegas et al. 2013, Peiter et al. 2015); however, in our study, this correlation did not occur. In a study conducted in the micro-region of Francisco Beltrão, 41\% of cattle was diagnosed with leptospirosis, with the Hardjo serovar being present in $81 \%(104 / 129)$ of the samples, and Wolffi serovar present in 29\% (38/129) (Peiter et al. 2015).

The Hebdomadis and Wolffi serovars had similar prevalence to the one reported in other Brazilian studies (Peiter et al. 2015). Menegas et al. (2013) studied aborted animals and found $53 \%$ seropositivity, presenting titers for one or more serovars. These authors indicated leptospirosis as the cause of abortions, as well as reporting the Hardjo serovar as the most common one in Paraná.

Concurrent infection with more than one type of serovar was found in 39\% (13/33) of the animals studied, than shorter that Menegas et al. (2013) reported that $52 \%$ of the animals presented reactivity for more than one serovar. Note that this study suggests a public health issue, since the Icterohaemorrhagiae serovar is very common in humans and can result in more severe patients (Guidi 2006, Pelissari et al. 2011).

Vaccination for leptospirosis, performed in $26 \%$ of the analyzed cattle, indicates that there is vaccine interference in the results, and this variation depends on the serovars tested, Pereira et al. (2013) reported that vaccination against leptospirosis is a way to increase reproductive efficiency and should be implemented in herds that will carry out artificial insemination programs. However, most serovars do not induce nonspecific reaction. It is also known that after 60 days of vaccination this influence decreases, but it reaches up to 240 days, as in the case of the Icterohaemorrhagiae serovar (Nardi Júnior et al. 2006). While most animals were not vaccinated $(73 \%)$, which minimizes the interference on the results, the vaccination period was not evaluated, which could explain the higher prevalence of the Icterohaemorrhagiae serovar.

About neosporosis, detected in 15\% (13/84) of animals, Langoni et al. (2013) reported 24\% (23/94) of bovines with anti-Neospora caninum antibodies with titer ranging from 25 to 400, in the state of Paraná. Camillo et al. (2010) reported a prevalence of $24 \%$ (431/1778) of animals with neosporosis, higher than that found in the present experiment. However, the authors consider seropositive animals those with titer greater than or equal to 1:100. Despite the seropositive samples in a large number of the animals of the herd, a study in Canada carried out by Waldner (2005) stated that the use of large-scale diagnostic tests is questionable because of the high cost.

Santos et al. (2005) studied the prevalence of brucellosis, leptospirosis and neosporosis in animals with a history of miscarriage in Paraná, and found that $60 \%$ (21/35) were reactive to one of the diseases. From the 21 positive animals, $14.3 \%$ were for neosporosis, $42 \%$ for leptospirosis and no animals were reactive to brucellosis, resembling the results obtained herein. For the seropositivity diagnosis, Santos et al. (2005) considered titers higher than or equal to 1:200, similar to the one as used in this study. Langoni et al. (2013) reported that the titration used is one of the important factors when estimating the prevalence of Neospora caninum, along with other factors such as race and test used.

Macedo et al. (2013) used ELISA diagnosis and found 15\% of seropositive beef cattle, similar to the prevalence found in this study, showing that race and dairy ability were not relevant for the prevalence of this agent.

Immunosuppression may be related to the synergism of infectious agents (Santos et al. 2005). Thus, the concomitant infection of different infectious agents may result in increased reproductive losses associated with abortion and retained placenta. On the other hand, only $4 \%$ of animals in this study presented an association between leptospirosis and neosporosis.

\section{CONCLUSION}

The population of dairy cattle with retained placenta of this study presented seropositivity for leptospirosis and/or neosporosis; no animals were diagnosed as positive for brucellosis.

\section{REFERENCES}

Alhaji N.B., Wungak Y.S. \& Bertu W.J. 2016. Serological survey of bovine brucellosis in Fulani nomadic cattle breeds (Bos indicus) of North-central Nigeria: potential risk factors and zoonotic implications. Acta Tropica 153:28-35. <http://dx.doi.org/10.1016/j.actatropica.2015.10.003> <PMid:26464048>

Bannantine J.P., Olsen S.C., Kehrli Junior J.R.M.E., Stanton T.B., Casas E., Whipple D.L. \& Zuelke K.A. 2013. High-impact animal health research conducted at the USDA's National Animal Disease Center. Vet. Microbiol. 165(3/4):224-233. <http://dx.doi.org/10.1016/j.vetmic.2013.04.010> $<$ PMid:23642415>

Brasil 2006. Programa Nacional de Controle e Erradicação da Brucelose e Tuberculose (PNCEBT). Ministério da Agricultura, Pecuária e Abastecimento, Brasília. 188p. Available at <http://www.agricultura.gov.br/arq_editor/file/ Aniamal/programa\%20nacional\%20sanidade $\% 20$ brucelose/Manual\%20 do\%20PNCEBT\%20-\%200riginal.pdf> Access on July 5, 2017.

Brasil 2011. Regulamento Técnico de Produção, Identidade e Qualidade do Leite tipo A, de Leite Cru Refrigerado, de Leite Pasteurizado e o Regulamento Técnico da Coleta de Leite Cru Refrigerado e seu Transporte a Granel, em conformidade com os Anexos desta Instrução Normativa. Instrução Normativa n.62 de 29 de dezembro de 2011, Diário Oficial da República Federativa do Brasil, Ministério da Agricultura, Pecuária e Abastecimento. Available at <http://www.leitedascriancas.pr.gov.br/arquivos/File/ legislacao/IN62_2011_MAPA.pdf> Access on July 5, 2017. 
Camillo G., Cadore G., Cezar A.S., Toscan G., Bräunig P., Sangioni L.A. \& Vogel F.S.F. 2010. Anticorpos anti-Neosporacaninum em bovinos de leite do sudoeste do estado do Paraná. Arq. Bras. Med. Vet. Zootec. 62(6):15111513. <http://dx.doi.org/10.1590/S0102-09352010000600033>

Carvalho R.P., Rabbers A.S., Dutra H.T., Silva K.S., Batista J.F., Lima C.R.O. \& Rabelo R.E. 2014. Neosporose bovina: revisão de literatura. Revta Cient. Med. Vet. 12(23):1-23. Available at <http://faef.revista.inf.br/imagens_ arquivos/arquivos_destaque/dZwny45dtKf9r9F_2014-7-27-16-29-52. pdf> Access on July 5, 2017.

Clementino I.J. \& Azevedo S.S. 2016. Bovine brucellosis: epidemiological situation in Brazil and disease control initiatives. Semina, Ciênc. Agrárias 37(4):2021-2034.

Dias J.A., Müller E.E., Dias R.A., Freitas J.C., Amaku M., Ferreira F., Silva M.C.P., Lôbo J.R., Figueiredo V.C.F., Gonçalves V.S.P. \& Ferreira Neto J.S. 2009. Situação epidemiológica da brucelose bovina no Estado do Paraná. Arq. Bras. Med. Vet. Zootec. 61(Suppl.1):66-76. <http://dx.doi.org/10.1590/ S0102-09352009000700009>

Dirksen G., Gründer H.D. \& Stöber M. 1993. Rosenberger: exame clínico dos bovinos. $3^{\mathrm{a}}$ ed. Guanabara Koogan, Rio de Janeiro. 419p.

Greca Junior H. 2010. Infecção por Leptospira spp e Neospora caninum, em rebanho bovino leiteiro: avaliação dos aspectos produtivos e reprodutivos. Dissertação de Mestrado, Universidade Estadual Paulista, Botucatu, SP. 63p.

Guidi R.C. 2006. Leptospirose em pequenos animais. Monografia de Especialização, Universidade Castelo Branco, Rio de Janeiro, RJ. Available at <http://docplayer.com.br/12783783-Universidade-castelo-brancoespecializacao-latu-sensu-clinica-medica-de-pequenos-animais.html> Access on July 5, 2017.

Hashimoto V.Y., Garcia J.L., Spohr K.A.H., Silva F.G., Alves L.A. \& Freitas J.C. 2010. Prevalência de anticorpos contra Leptospira spp. em bovinos, caninos, equinos, ovinos e suínos do município de Jaguapitã, estado do Paraná, Brasil. Arqs Inst. Biológico, São Paulo, 77:521-524.

Hashimoto V.Y., Dias J.A., Spohr K.A.H., Silva M.C.P., Andrade M.G.B., Müller E.E. \& Freitas J.C. 2012. Prevalência e fatores de risco associados à Leptospira spp. em rebanhos bovinos da região centro-sul do estado do Paraná. Pesq. Vet. Bras. 32(2):99-105. <http://dx.doi.org/10.1590/S0100736X2012000200001>

IAPAR 2015. Cartas climáticas do Paraná. Instituto Agronômico do Paraná. Available at <http://www.iapar.br/modules/conteudo/conteudo. php?conteudo=863> Access on July 5, 2017.

IBGE 2017. Mapas. Instituto Brasileiro de Geografia e Estatítica. Available at <http://mapas.ibge.gov.br/bases-e-referenciais/bases-cartograficas/ malhas-digitais.html $>$ http://www.iapar.br/modules/conteudo/conteudo. php?conteudo $=863$

Juffo G.D. \& Driemeier D. 2010. Aborto em bovinos principais causas infecciosas. Monografia em Patologia Animal, Faculdade de Veterinária, Universidade Federal do Rio Grande do Sul, Porto Alegre, RS. 28p. Available at <http:// www.lume.ufrgs.br/bitstream/handle/10183/39020/000792782.pdf> Access on July 5, 2017.

Langoni H., Silva A.V., Cagnini S.K.F. \& Ribeiro C.M. 2013. Avaliação sorológica para Neospora caninum em propriedades de bovinos leiteiros com alterações reprodutivas. Vet. Zootec. 20:124-130.

Laven R.A. \& Peters A.R. 1996. Bovine retained placenta: aetiology, pathogenesis and economic loss. Vet. Rec. 139(19):465-471. <http://dx.doi.org/10.1136/ vr.139.19.465><PMid:8938967>

Macedo C.A.B., Macedo M.F.S.B., Cardim S.T., Paiva M.C.D.C., Taroda A., Barros L.D., Cunha I.A.L., Zulpo D.L. \& Garcia J.L. 2013. Neospora caninum: evaluation of vertical transmission in slaughtered dairy cows (Bos taurus). Revta Bras. Parasitol. 22(1):13-17. <http://dx.doi.org/10.1590/S198429612013000100004><PMid:24252950>
Magajevski F.S., Gírio R.J.S. \& Meirelles R.B. 2007. Pesquisa de leptospira em fetos de vacas abatidas no Estado de São Paulo, Brasil. Arqs Inst. Biológico, São Paulo, 74:67-72.

Menegas P.H., Tonette G., Oliveira L.A., Freitas J.C. \& Gonçalves D.D. 2013. Leptospirose em propriedade rural com histórico de aborto bovino da região centro-sul do Estado do Paraná: relato de caso. Enciclopédia Biosfera 9(17):1783-1792.

Mineiro A.L.B.B., Bezerra E.E.A., Vasconcellos A.S., Costa F.A.L. \& Macedo N.A. 2007. Infecção por leptospira em bovinos e sua associação com transtornos reprodutivos e condições climáticas. Arq. Bras. Med. Vet.Zootec. 59(5):11031109. <http://dx.doi.org/10.1590/S0102-09352007000500003>

Mufinda F.C., Boinas F. \& Nunes C. 2017. Prevalência e factores associados à brucelose humana em profissionais da pecuária. Revta Saúde Pública 51:57. <http://dx.doi.org/10.1590/S1518-8787.2017051006051>

Nardi Júnior G., Ribeiro M.G., Vasconcellos A.S., Megid J., Jorge A.M., Geronutti L. \& Morais Z.M. 2006. Perfil de aglutininas anti-Leptospira em bezerras búfalas vacinadas com bacterina pentavalente comercial contra leptospirose. Arq. Bras. Med. Vet. Zootec. 58(3):299-304. <http://dx.doi.org/10.1590/ S0102-09352006000300002>

Nascimento E.F. \& Santos R.L. 2011. Patologias do útero, p.63-78. In: Ibid. (Eds), Patologia da Reprodução dos Animais Domésticos. Guanabara Koogan, Rio de Janeiro.

Nascimento J.E.F., Dias R.V.C. \& Câmara A. 2008. Levantamento sorológico de brucelose bovina no município de Cajazeiras/PB. Acta Vet. Bras. 2:44-46.

Negrão C.B. 2006. A importância do Neospora caninum na reproduçâo de bovinos. Tese de Doutorado, Universidade Estadual Paulista, Botucatu, SP

Nielsen K. \& Yu W.L. 2010. Serological diagnosis of brucellosis. Prilozi Contributions, Sec. Biol. Med. Sci. 31(1):65-89.

Nobre M.M., Coelho S.G., Haddad J.P.A., Campos E.F., Lana A.M.Q., Reis R.B. \& Saturnino H.M. 2012. Avaliação da incidência e fatores de risco da retenção de placenta em vacas mestiças leiteiras. Arq. Bras. Med. Vet. Zootec 64(1):101-107. <http://dx.doi.org/10.1590/S0102-09352012000100015>

Palmquist 0. 2001. Contribuição ao conhecimento da incidência da brucelose no Estado do Paraná, Brasil. Braz. Arch. Biol. Tech. 1(0):307-309. <http:// dx.doi.org/10.1590/S1516-89132001000500014>

Parra B.C., Scaramucci B.S. \& Pirizzotto C. 2008. Neosporose uma doença que acomete abortos em bovinos. Revta Cient. Eletrôn. Med. Vet. 6(10):1-6. Available at $<\mathrm{http}: / /$ faef.revista.inf.br/imagens_arquivos/arquivos_destaque/ Ey8sg9GnM4rEXIG_2013-5-29-9-57-54.pdf> Access on July 5, 2017.

Peiter M., Rocha J.F.X., Pivoto F.L., Aires A.R., Rocha R.X., Bragança J.F.M., Ferreira A.G.T. \& Leal M.L.R. 2015. Prevalência sorológica de Leptospira spp. em bovinos leiteiros na microrregião de Francisco Beltrão. Vet. Zootec. 22(3):392-395.

Pelissari D.M., Maia-Elkhoury A.N.N.S., Arsky M.L.N.S. \& Nunes M.L. 2011 Revisão sistemática dos fatores associados à leptospirose no Brasil 2000-2009. Epidemiol. Serviços Saúde 20(4):565-574. <http://dx.doi. org/10.5123/S1679-49742011000400016>

Pereira M.H.C., Cooke R.F., Alfieri A.A. \& Vasconcelos J.L.M. 2013. Effects of vaccination against reproductive diseases on reproductive performance of lactating dairy cows submitted to AI. Anim. Reprod. Sci. 137(3/4):156-162. <http://dx.doi.org/10.1016/j.anireprosci.2012.12.011><PMid:23357089>

Rezende E.V., Campos C.C. \& Santos R.M. 2013. Incidência da retenção de placenta e as consequências na produção de leite e na eficiência reprodutiva de vacas holandesas. Acta Scient. Vet. 41:1-6.

Rifatbegović M. \& Maksimović Z. 2011. Serological study of leptospirosis among dairy cattle in Bosnia and Herzegovina. J. Vet. Anim. Sci. 36:459-462.

Sabedot M.A., Boetcher A.V., Pozza M.S.S., Busanello M. \& Mangoni J. 2009. Ocorrência de tuberculose e brucelose em rebanhos da região sudoeste do Paraná. Revta Cient. Eletrôn. Med. Vet. 7(12):1-9. Available 
at <http://faef.revista.inf.br/imagens_arquivos/arquivos_destaque/ TWlFqvD9Wrivjwa_2013-6-18-15-57-10.pdf> Access on July 5, 2017.

Santos A.P.M.E., Navarro I.T., Bracarense A.P.F.R.L., Freire R.L., Marana E.R.M., Ogawa L., Alfieri A.A., Freitas J.C. \& Vidotto O. 2005. Dairy cow abortion associated with Neospora caninum and other infectious agents. Arq. Bras. Med. Vet. Zootec. 57(4):545-547. <http://dx.doi.org/10.1590/S010209352005000400017>

Santos J.E.P. 2010. Doenças uterinas em vacas de leite: prevalência, fatores de risco e tratamento. Anais do Curso Novos Enfoques na Produção e Reprodução de Bovinos, Uberlândia, MG, p.393-410. (Resumo)

Sartori F. \& Luguesi A. 2011 Prevalência de brucelose e tuberculose no município de Bom Jesus do Sul, sudoeste do Paraná. Monografia de Especialização, Universidade Tuiuti do Paraná, Cascavel, PR. Available at $<$ http://tcconline.utp.br/wp-content/uploads//2011/10/PREVALENCIADE-BRUCELOSE-E-TUBERCULOSE-NO-MUNICIPIO-DE-BOM-JESUS-DOSUL-SUDOESTE-DO-PARANA.pdf> Access on July 5, 2017.

Teixeira W.C., Uzêda R.S., Gondim L.F.P., Silva M.I.S., Pereira H.M., Alves L.C. \& Faustino M.A.G. 2010. Prevalência de anticorpos anti-Neospora caninum (Apicomplexa: Sarcocystidae) em bovinos leiteiros de propriedades rurais em três microrregiões no estado do Maranhão. Pesq. Vet. Bras. 30(9):729734. <http://dx.doi.org/10.1590/S0100-736X2010000900004>

Tembue A.A.S.M., Ramos R.A.N., Sousa T.R., Albuquerque A.R., Costa A.J., Meunier I.M.J., Faustino M.A.G. \& Alves L.C. 2011. Serological survey of Neospora caninum in small ruminants from Pernambuco State, Brazil. Revta Bras. Parasitol. 20(3):246-248. <http://dx.doi.org/10.1590/S198429612011000300013><PMid:21961757>

Viana K.F., Moraes G.C. \& Zanini M.S. 2009. Frequência de anticorpos antiBrucella abortus em Rebanhos bovinos de aptidão leiteira no município de Alegre, estado do Espírito Santo. Acta Vet. Brasilica 3:13-15.

Waldner C.L. 2005. Serological status for N. caninum, bovine viral diarrhea virus, and infectious bovine rhinotracheitis virus at pregnancy testing and reproductive performance in beef herds. Anim. Reprod. Sci. 90(3/4):219-242. <http://dx.doi.org/10.1016/j.anireprosci.2005.03.017><PMid:15893892>

Zago M.M. 2011. Levantamento sobre Brucelose Bovina no Estado do Paraná. Monografia de Especialização em Gestão em Defesa Agropecuária com ênfase em Sanitária Animal, Universidade Federal do Paraná, Curitiba, PR. 42p. Available at <http://acervodigital.ufpr.br/bitstream/ handle/1884/38730/R\%20-\%20E\%20-\%20MARCIA\%20MARIA $\% 20$ ZAGO.pdf?sequence $=2>$ Access on July 5, 2017 . 